\title{
MEIS1 Gene
}

National Cancer Institute

\section{Source}

National Cancer Institute. MEIS1 Gene. NCI Thesaurus. Code C24590.

This gene plays a role in embryonic development and cell differentiation. 